УДК 81'253-057.54; 811.531

DOI: $10.18384 / 2310-712 \mathrm{X}-2019-4-125-130$

\title{
BBB KOREA AND ITS CONTRIBUTION TO HUMAN COMMUNICATION
}

\author{
Bang Gyo-young \\ Hankuk University of Foreign Studies \\ 280 Imun-dong, Dongdaemun-gu, Seoul, South Korea
}

\begin{abstract}
The paper describes the role and functions of the BBB Korea, the world's only nongovernmental organization providing volunteer interpreting service to overcome language barriers at visiting Korea Republic. The author offers the review of the organization history from the moment of its foundation, analyzes the reasons for forming the organization, its purposes and goals. The statistics of references to the organization is summarized, which gives a comprehensive overview of the real work of interpreters-volunteers, as well as demand for their work during significant sports actions, national holidays and other events. Classification of typical questions to the interpreters-volunteers is presented, institutions to which inquiries are directed are analyzed. The article also deals with the concept of "digilog", combining digital devices, smartphone, in particular, with corresponding volunteer activity. A general overview of BBB activity is also presented. The activity goes beyond interpretation: BBB hosts International Friends Day which brings together local Koreans and foreigners. It is also running Korean language schools in four countries in Southeast Asia, in an effort to facilitate cultural exchange and promote Korean culture.
\end{abstract}

Keywords: BBB Korea, Interpreting service, volunteer, digilog, international communication

\section{ВВВ КОRЕА И ЕЁ ВКЛАД В МЕЖКУЛЬТУРНУЮ КОММУНИКАЦИЮ}

\author{
Пан Кё Ён \\ Университет иностранных языков Хангук \\ 280, г. Сеул, Тонгдэмун-гу, Имунг-донг, Республика Корея
}

\begin{abstract}
Аннотация. В статье описаны роль и функции организации волонтёров-переводчиков, называемой $B B B$ Korea, единственной в мире негосударственной организации, созданной для преодоления языковых барьеров при посещении Республики Кореи. Автор предлагает обзор состояния организации с момента её создания, анализирует причины возникновения данной организации, её цели и задачи. Приводится статистика обращений к данной организации, позволяющая получить представление о реальной работе волонтёров-переводчиков, их востребованности во время значимых спортивных мероприятий, национальных праздников и других мероприятий. Приводится классификация типовых вопросов к службе волонтёров-переводчиков, анализируются учреждения, на которые ориентированы запросы. В статье рассматривается понятие «дигилога», сочетающего в себе цифрровые устройства, в частности смартфон, с аналоговой активностью (волонтёрской службой). Отдельно описывается деятельность $B B B$, выходящая за пределы собственно устного перевода, а именно проведение Международного дня друзей, собирающего

(ㄷ) СС ВY Пан Кё Ён, 2019.
\end{abstract}


вместе жителей Кореи и иностранцев, а также организацию языковых школ по изучению корейского языка в четырёх странах Юго-восточной Азии, что способствует культурному обмену и распространению знаний о корейской культуре.

Ключевые слова: ВBВ Korea, волонтёр-переводчик, устный перевод, дигилог, межкультурная коммуникация

\section{Introduction: An outline history}

The BBB is abbreviation of 'Before Babel Brigade', as its official site explains, "organization's wish - to restore the world to the state before the Babel Tower, during which the human race shared one language and had no problem in communication". The BBB Korea was established in 2002 to support the FIFA World Cup Korea and Japan by helping visitors from overseas with language problems. It provided over 20,000 times of volunteer telephone interpreting service in 13 languages throughout the two-month sporting event. For the Busan Asian Games held in the same year, the $\mathrm{BBB}$ provided interpreting service in 17 languages.

Its service comprises 19 languages: English, Chinese, Russian, Swedish, Japanese, German, Portuguese, French, Arabic, Spanish, Polish, Italian, Turkish, Vietnamese, Malaysian, Indonesian, Thai, Mongolian and Indian. The non-profit organization is funded by the Korean Ministry of Culture, Sports and Tourism and a number of corporate sponsors. Request for interpreting service is made on the phone. Anyone can dial BBB's key number (1588-5644) and request for interpreting service. Its smartphone application is also available to download ${ }^{2}$.

Interpreters at the $\mathrm{BBB}$ are not paid professionals, but civic volunteers. They

${ }^{1}$ About BBB Korea. In: BBB Korea. Available at: https://www.bbbkorea.org/global/eng/bbbkorea/ institution.php (accessed: 10.05.2019).

${ }^{2}$ How to use. In: BBB Korea. Available at: https://www.bbbkorea.org/en (accessed: 10.05.2019). come from diverse backgrounds, such as businessmen, executives, overseas project managers, clerks, legal, medical and religious practitioners, (under)graduate students majoring in the language, housewives, retired diplomats, high-level government officials, and CEOs. There are some professional interpreters, who work with $\mathrm{BBB}$ free of charge. BBB does not provide any interpreting service towards personal gain; it does not provide service for business or language learning purposes, and volunteers can decline a request, if they feel it should be referred to professional interpreting service. Its interpreting service is provided on the phone only, and in principle does not cover face-toface communication. The BBB volunteers, who should be 20 or older in age, are selected on the basis of document assessment and over-the-phone test. The BBB is a citizen participation program that provides translation service in real time when people are placed in difficult communication situations at airports, hospitals, shopping malls, and police stations. Clients do not need to pay extra money besides the basic phone bill.

The BBB Korea has not just been supporting major sporting events or international gatherings, but has also been providing day-to-day interpreting service for visitors to Korea and Koreans traveling overseas facing communication problems. It operates in partnership with some 50 public and private organizations including airports, local municipalities with a large number of foreign tourists/resi- 
dents, hospitals (to provide emergency medical support and promote healthcare tourism), police stations, organizing committees for international events, other institutions/enterprises concerning support for foreigners and organizations in Korea dealing with foreign languages.

International Events BBB has assisted so far include 2002 Korea-Japan World Cup Games, 2002 Busan Asian Games, 2003 Gyeongju World Culture EXPO, 2003 Daegu University Games, 2005 APEC summit in Busan, 2008 Beijing Olympic Games (Hotline), 2010 G-20 Seoul summit, IAAF World Championships Daegu 2011, 2012 Yeosu World EXPO, 2014 FIFA Brazil Worldcup (Rio Amigo), 2014 Incheon Asian Games and Incheon 2014 Asian Para Games ${ }^{1}$.

\section{Some statistics}

The BBB provided total 409,194 times of interpreting service from 2002 to 2013. Its activity seemed to decline for two immediate years following the 2002 World Cup games, when it was in the process of promoting itself and extending its scope of work to non-World Cup areas. Interpreting service for tourists went down compared to 2002, while service for resident foreigners increased. Picking up again from 2005, its work exceeded the 2002 level in 2007, indicating its penetration into civic society. The use of BBB's service has been soaring for the last few years, as Korea hosted a number of international events.

To take a closer look at the year 2013, there was no major sporting event, nor any other international conferences inviting a large number of foreigners into Ko-

${ }^{1}$ Heart \& Communication. In: BBB Korea. Available at: https://www.bbbkorea.org/en/history. php (accessed: 10.05.2019) rea, and yet, BBB still served 67,514 calls. The BBB was more active in the middle and at the end of the year, compared to the beginning, providing more service in July and August, the peak season for tourism, than any other month. The most frequently used foreign language for interpreting was English, not necessarily because of visitors from English-speaking countries, but because of foreigners from non-English-speaking countries trying to communicate with Koreans in English and turning to BBB for help.

The number of volunteer interpreters at BBB has been on a steady rise since 2002, and currently there are total 4,453 interpreters working in 19 different languages including Mongolian and Indian added to its language portfolio in 2011 and 2013 respectively. The volunteers can be reached 24 hours and 7 days a week via their own mobile phones. The BBB has 1,873 English interpreters accounting for the biggest proportion, followed by Japanese (931), Chinese (777), Spanish (167), Russian (133) and French (101) interpreters. Volunteers working in German (93), Arabic (56), Malaysian/Indonesian (71), Italian (46), Mongolian (44), Vietnamese (43) and Thai (39) are also quite many ${ }^{2}$.

Requests for English, Chinese and Russian increased approximately 10 times from 2002 to 2013. The proportion of English and Japanese has been decreasing, but at a modest pace. Meanwhile, requests for minority languages including Vietnamese, Thai and Malaysian/Indonesian are increasing continuously; requests for Thai interpreting soared 90 times, a record increase, from 2002 to 2013, while requests for Vietnamese telephone inter-

${ }^{2}$ Volunteers. In: BBB Korea. Available at: https:// www.bbbkorea.org/en/volunteer.php (accessed: 10.05.2019). 
preting showed a 12 -fold increase from 2002 to 2005 . This mirrors the changing Korean society and increasing international exchange which took place for the last several years. Increasing demand for Vietnamese interpreting service, in particular, is in line with the unique phenomenon of more and more Korean men marrying Vietnamese women.

The BBB's partnering with the National Police Agency in 2005 has allowed for typological classification of interpreting service requests. Requests concerning guidance for daily life, asking directions, police matters, tourism and accommodation accounted for 85 percent of all requests from 2002 to 2007. Examples include interpreting service provided for someone who needs help for his Moroccan nephew visiting Korea, asking directions at airports and train stations, in emergency rooms, and those involved in police matters such as crimes/accidents, certificate/document issuance, lodging of lost report, etc.

Location backgrounds of interpreting service requests as of 2013 include police stations, taxis, shops, hospitals, airports and train stations. The users of BBB service have shifted from tourists and tourism industry workers in the times of the 2002 soccer games, to police, public transportation workers, service industry workers and ordinary citizens, as well as those in the tourism industry, indicating BBB's activity is increasingly diverse and specialized. BBB's outreach efforts and committed volunteers are thought to be one of the major driving forces behind its growth and specialization [1].

\section{The BBB Korea and Globalization}

The volunteer telephone interpreting service model of BBB Korea, which is based on a digilog concept combining digital device (mobile phone) with analog activity (volunteering), was exported to Brazil for use in the 2014 FIFA World Cup. The NGO, initially established to help ease language barriers for foreigners visiting Korea during the 2002 World Cup, has now become a permanent organization. It has undergone continuous extension and growth, not just in terms of the number of languages and volunteers, but also in terms of its service quality (Fig. 1). It is also noteworthy that they initially started off with inbound service only, but later added outbound service where users can access BBB's telephone interpreting service even from overseas. Aside from interpreting service, BBB Korea conducts other businesses related to language and culture. It hosts International Friends Day which brings together local Koreans and foreigners. It is also running Korean language schools in four countries in Southeast Asia, in an effort to facilitate cultural exchange and promote Korean culture.

One of the BBB's expansions was the global project Rio Amigo, which was introduced in Rio de Janeiro to provide interpreting service for the 2014 FIFA World Cup Brazil. The export of BBB model was coordinated by Rio Tourist Commission and Marilia Rebello\&Associdos, a company specializing in translation and interpreting. BBB and Marilia communicated via email, and named their project Rio Amigo which means 'Rio Friend' in Portuguese. In May, a few BBB members were sent to help set up the BBB volunteer system in Rio firsthand. The Rio Amigo team recruited 96 volunteers who were fluent in seven most frequently used languages, such as English, Spanish, Italian and Russian. After the World Cup, major media agencies such as O-Globo, USA 
Today and BBC news widely reported Rio Amigo project ${ }^{1}$.

The activity of BBB Korea has significantly lowered language barriers faced by foreigners who do not speak the local language. It also helps to understand different needs of foreigners in Korea (other than those fluent in Korean, diplomats to Korea or those on business trips) in different situa- tions. Though it is a case of Korea, the same method could, by all means, be adopted by other countries to understand communication patterns and purposes among foreigners in their respective countries. Knowing the present state of language service provides insight on upcoming changes in the field of interpreting, and ultimately on the future of human communication.

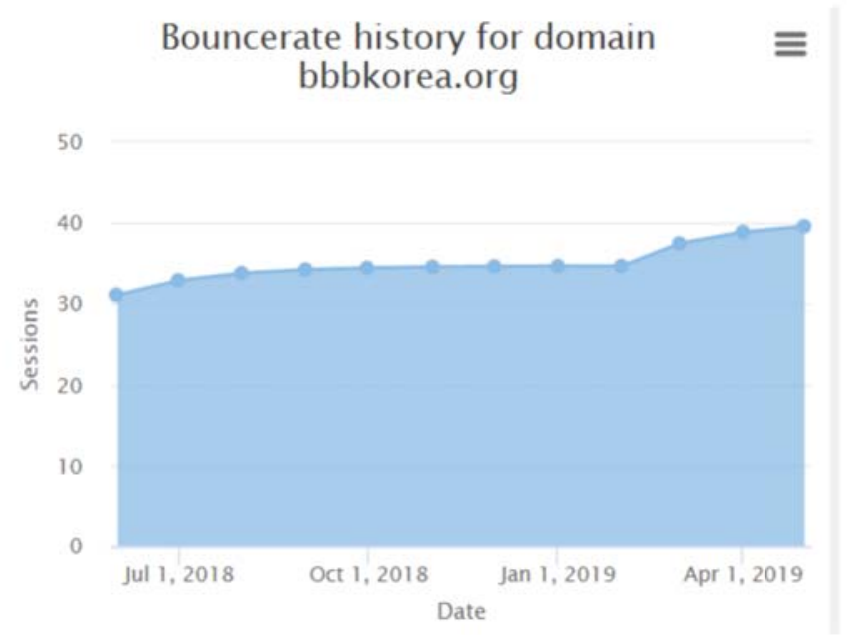

Figure 1. Bounce rate history for domain bbbkorea.org

In summary, the BBB Korea, a volunteer movement led by educated people in various occupations, both active and retired, teaches the joy of serving others. Besides, the natural segmentation between professional and non-professional interpreting activities promotes the notion of harmony between industrial and public dimensions, pursuing public benefit beyond commercial profit.

Secondly, the BBB Korea has embodied the growth and sustainability of volunteerism through a non-complicated model. Ex-

${ }^{1}$ bbb global project \#1, Brazil 'Rio Amigo'. In: $B B B$ Korea. Available at: https://www.bbbkorea. org/en/global.php (accessed: 10.05.2019). ported to Brazil in 2014, the simple model can be easily applied to almost every country, which would further promote the public benefit dimension of interpreting itself. $\mathrm{BBB}$ endeavors to expand its movement into other countries to grow into an international organization making the world a place free from language barriers.

Third, movements like BBB Korea could lead to collective confidence that language barriers can indeed be lowered or even be removed - a foundation on which human communication will continue to advance and prosper.

As it is declared on the site of BBB, "the slogan of BBB Korea is "Heart \& Com- 
munication", where heart symbolizes Korea's unique culture of "Jeong", emotional bonds between people and free volunteer work both of which Korea is based on. Communication signifies BBB Korea's de- termination to work toward a world of communication through mutual understanding of language and culture"1.

Статья поступила в редакцию 29.05.2019

\section{REFERENCES}

1. BBBMagazine Heart \& Communication. Vols. 1 to 34. Available at: URL: https://www. bbbkorea.org/ko/magazine.php (accessed: 10.05.2019).

\section{ИНФОРМАЦИЯ ОБ АВТОРЕ}

Пан Кё Ён - доктор наук, профессор, заведующая русским отделением аспирантуры устного и письменного перевода Университета иностранных языков Хангук, г. Сеул, Республика Корея;

e-mail: lenabahng@hanmail.net

\section{INFORMATION ABOUT THE AUTHOR}

Bang Gyo-young - PH.D. Professor, Head of the Russian Department of Graduate School of Interpreting \& Translation, Hankook University of Foreign Studies, Seoul, Republic of Korea; e-mail: lenabahng@hanmail.net

\section{ПРАВИЛЬНАЯ ССЫЛКА НА СТАТЬЮ}

Пан Кё Ён. ВВВ Когеа и её вклад в межкультурную коммуникацию // Вестник Московского государственного областного университета. Серия: Лингвистика. 2019. № 4. С. 125-130. DOI: $10.18384 / 2310-712 X-2019-4-125-130$

\section{FOR CITATION}

Bang Gyo-young. BBB Korea and its contribution to human communication. In: Bulletin of Moscow Region State University. Series: Linguistics, 2019, no. 4, pp. 125-130.

DOI: $10.18384 / 2310-712 X-2019-4-125-130$

${ }^{1}$ About BBB Korea. In: BBB Korea. Available at: https://www.bbbkorea.org/global/eng/bbbkorea/institution.php (accessed: 10.05.2019). 